\title{
MANAJEMEN PENGELOLAAN BUMDes MANDIRI SEJAHTERA
}

\author{
Jumaiyah $^{1 *}$, Wahidullah², Solikhul Hidayat ${ }^{3}$, Luky Mudiarti ${ }^{4}$, Siti Aliyah ${ }^{5}$ \\ ${ }^{1 *}$ Program Studi Akuntansi, Fakultas Ekonomi Dan Bisnis Universitas Islama Nahdlatul Ulama Jepara \\ ${ }^{2}$ Program Studi Perbankan Syari'ah Fakultas Syariah Dan Hukum Universitas Islama Nahdlatul Ulama Jepara \\ ${ }^{3}$ Program Studi Akuntansi, Fakultas Ekonomi Dan Bisnis Universitas Islama Nahdlatul Ulama Jepara \\ ${ }^{4}$ Program Budidaya Perairan, Fakultas Saintek Universitas Islama Nahdlatul Ulama Jepara \\ ${ }^{5}$ Program Studi Akuntansi, Fakultas Ekonomi Dan Bisnis Universitas Islama Nahdlatul Ulama Jepara \\ ${ }^{*}$ Corresponding author: \\ E-mail : mayawahidah@unisnu.ac.id
}

Diterima 19 Agustus 2019, Disetujui 4 September 2019

\begin{abstract}
ABSTRAK
Program pengabdian ini dilaksanakan pada BUMDes Mandiri Sejahtera Desa Pancur Kec. Mayong Kabupaten Jepara. Kegiatan ini berlangsung selama 6 Bulan tahun 2019. Usaha mitra di bidang simpan pinjam dan dagang. Kondisi mitra selama ini mengalami kredit macet,serta legalitas hukum yang kurang lengkap, dengan kondisi seperti itu mitra menjadi tidak semangat lagi untuk meneruskan usahanya di BUMDes. Berdasarkan kesepakatan dengan mitra, tim pelaksana akan memberikan solusi berupa workshop manajemen kredit macet, serta memberikan legalitas dan motivasi. Hasil dari kegiatan ini mitra menjadi paham dalam menagani kredit macet serta urus perijinan yang belum di miliki oleh BUMDes seperti ijin sertifikat halal dan BPOM.
\end{abstract}

Kata Kunci: BUMDes; Manajemen kredit; motivasi

\begin{abstract}
This service program is carried out at BUMDes Mandiri Sejahtera Desa Pancur Kec. Mayong, Jepara Regency. This activity will last for 6 months in 2019. Business partners in the field of savings and loans and trade. The condition of partners has been experiencing bad credit, as well as incomplete in law legality, with such conditions the partners are no longer eager to continue their business in BUMDes. Based on an agreement with partners, the implementation team will provide solutions in the form of bad credit management workshop, and provide legality and motivation. As a result of this activity the partners become aware of handling bad loans and take care of licenses that are not yet owned by BUMDes such as permits for halal certificates and BPOM.
\end{abstract}

Keywords: BUMDes, Credit management, Motivation.

\section{PENDAHULUAN}

BUMDes Mandiri sejahtera dirintis sejak Tahun 2016, mitra beralamat di Desa Pancur Kec, Mayong Kabupaten Jepara. BUMDes Mandiri Sejahtera bergerak dibidang usaha dangang dan Simpan Pinjam. Usaha yang dirintis adalah Mini Market dengan menyediakan kebutuhan masyarakat seperti sembako dan kebutuhan sehari-hari. Sementara usaha simpan pinjam berjalan kurang lancer serta mengalami kemacetan. Selama ini mitra dakam memberikan pinjaman kurang selektif. Untuk menjalankan usaha simpan pinjam BUMDes ini mempunyai 3 (tiga ) orang karyawan. Sementara usaha minimarket ada 2 orang karyawan, satu untuk bagian kasir sementara satunga konsentrasi bagian pelayanan barang dan kemasan. Asset yang dimiliki oleh mitra tertanggal 31 Desember 2018 sebesar Rp. 30.000.000,sementara omset yang dihasilkan oleh mitra dari usaha minimarket rata-rata setiap bulanya sebesar Rp. 3.000.000,-Rp.4.000.000,- selain usaha diatas mitra mempunyai usaha air bersih.

BUMDes Mandiri Sejahtera ini terkesan tidak teradministrasi dengan baik. Hal ini dikarenakan tidak adanya staf yang focus mengurusi administrasi khusus bagian keuangan, serta tidak ada karyawan khusus nagani nasabah untuk penarikan pinjaman. Disisi lain terdapat keharusan untuk membuat laporan keuangan untuk mengetahui berapa laba usaha, berapa asset BUMDes, bertambah atau justru berkurang, berapa peminjam BUMdes dan berapa yang sudah mengembalikan, berapa piutang tak tertagih. semua itu belum di ketahui oleh meneger BUMDes. Sehingga yang terjadi setiap akhir tahun menyusun laporan keuangan yang belum sesuai dengan standar akuntansi pada umumnya. 
Kredit macet yang dialami mengalami masalah tersendiri. Hal ini akan menjadi penghambat berkembangnya BUMDes. Dalam proses peminjaman dari lembaga perbangkan yang menyebabkan perusahaan sulit berkembang dan asetnya berkurang karena ada piutang tak tertagih. Jika penyakit kredit macet ini di biarkan, maka penyakit ini akan menjadi parah yang menyebabkan BUMDes kerdit atau tidak berkembang.

\section{METODE}

Metode yang akan dilakukan untuk mengatasi permasalahan mitra adalah sebagai berikut; 1] Melakukan Sosialisasi program kepada mitra. 2] Tim pengusul akan melakukan sosialisasi kepada kepala desa setempat, serta mitra tentang rencana pengabdian masyarakat. 3] Melakukan Pelatihan-Pelatihan yang diperlukan oleh mitra. Dalam kegiatan ini tim pengabdi akan melaksanakan pelatihan-pelatihan yang diperlukan oleh mitra, diantaranya adalah: pertama Pelatihan Manajemen Kredit macet. Kegiatan ini dilaksanakan dengan metode presentasi dan simulasi dikelas. Pelatihan ini dilaksanakan secara manual terlebih dahulu. Setelah mitra memahami, selanjutnya pelatihan dilanjutkan dengan simulasi penanganan keredit macet. Kedua Wokshop pentingnya legalitas dan motivasi badan usaha

\section{PEMBAHASAN}

Kegiatan yang dilaksanakan salah satunya adalah pelatihan, Pelatihan ini dilaksanakan pada hari Kamis tanggal 16 Mei 2019 mulai pukul 08.00 wib sampai dengan pkl 16.30 wib. Kegiatan ini diikuti oleh 15 orang peserta (susunan acara dan daftar hadir terlampir). Kegiatan dilakukan dengan pembacaan tahlil yang dipimpin oleh Bpk Wahidullah, SHI,M.SH. Adapun materi-materi yang disampaikan sebagai berikut:

a. Pentingnya legalitas dan motivasi badan usaha

Pelatihan ini di sampaikan oleh Bpk Wahidullah, SHI,MH. Pada pelatihan ini di awali dengan berbagai motivasi dan pemutaran film yang berkaitan dengan motivasi, kemudian penjelasan narasumber, serta Tanya jawab langsung berkaitan dengan promlematika perijinan BUMDes Desa pancur. Pada saat pemutaran film peserta antusias sekali menyimak film yang disaksikan. Film yang bertemakan dengan semangat kerja ini di anggap berhasil membawa emosi peserta pelatihan. Antusias ini di ukur dari pernytaan peserta setelah pemutaran film. Seelah pemutaran film dilanjutkan dengan materi legalitas hokum. Peserta di minta menmbaca undang-undang kaitanya dengan BUMDes kemudian dilanjutkan dengan paparan narasumber tentang legalitas BUNDes. Dari pengakuan peserta BUMDes hanya mempunyai akte pendirian saja, selebihnya tidak ada. Ini menunjukan bahwa ada PR bagi pengurus BUMDes untuk melengkapi legal formalnya kaitanya dengan usaha seperti ijin usaha, sertifikat halal serta ijin BPOM mengingat mitra usaha air minum, serta makanan ringan.

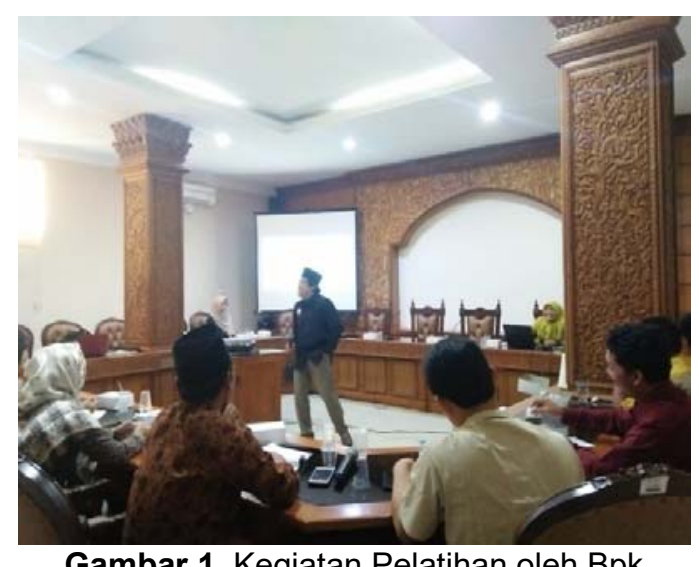

Gambar 1. Kegiatan Pelatihan oleh Bpk Wahidullah, SHI, MH.

\section{b. Manajemen kredit macet}

Pelatihan ini berbentuk brainstorming yang membaca persoalan berdasarkan informasi peserta pelatihan, setelah dirasa cukup fasilitator memberikan materi sesuai dengan persoalan yang ada. Adapun materi yang di sampaikan seputar menajeman kredit macet pada umumnya. Materi ini di sampaikan oleh ibu Jumaiyah, SE.M.Si. kegiatan ini di mulai dengan merekam semua persoalan yang ada pada mitra. Dengan menggali berapa kredit yang dikucurkan? berapa nasabahnya? Berapa keredit yang macet? Dari berapa nasabah kerdit yang macet? Dari persolalan yang ada maka fasilitator menguraikan permasalahan tersebut dengan solusi yang ditawarkan kepada mitra. 


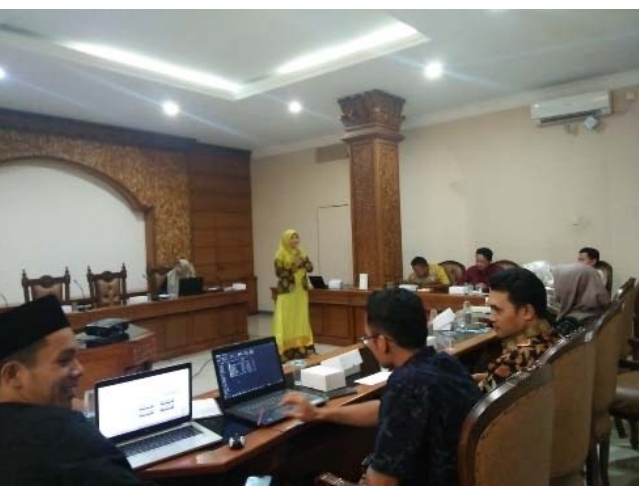

Gambar 1. Kegiatan Pelatihan oleh ibu Jumaiyah, SE.M.Si

\section{SIMPULAN}

Dari kegiatan yang dilakukan oleh tim pengabdian manfaat bisa langsung di rasakan oleh mitra di antaranya adalah mitra termutivasi lagi untuk memulai bekerja lagi dengan pemecahan solusi yang di tawarkanya. Dalam hal legalitas mitra mengetahui kekurangan ya yang kemudian surat ijin akan dilengkapi dengan system pendampingan dari tim pengabdi. Pada kasus kredit macet, mitra akan menelusuri ulang siapa saja yang mengalami kredit macet, dan akan dilakukan kontrak baru dengan nasabah yang mengalami kredit macet tersebut.

\section{DAFTAR RUJUKAN}

Buku Panduan Pengabdian Reguler Unisnu Jepara TA. 2018 / 2019

Peraturan Menteri Desa, Pembangunan Daerah Tertinggal dan Transmigrasi No. 4 Tahun 2015 Tentang Pendirian, Pengurusan dan Pengelolaan, dan Pembubaran Badan Usaha Milik Desa.

Peraturan menteri keuangan republik Indonesia No 4 Tahun 2015 tentang Badan Usaha Milik Desa

Peraturan Pemerintah No. 43 tahun 2014 tentang Peraturan Pelaksanaan Undang Undang Nomor 6 tahun 2014 tentang Desa

Peraturan Pemerintah Nomor 47 tahun 2015 tentang Perubahan Peraturan Pelaksanaan Undang Undang nomor 6 tahun 2014 tentang Desa; dan

Undang-Undang Republik Indonesia Nomor 6 Tahun 2015 Tentang Desa 